\title{
Preliminary Design of A Model Computerised Economic Growth Monitoring System
}

\author{
UGWOKE, F. N. \\ Computer Science Department,Michael Okpara University of Agriculture,Umudike,Abia State, Nigeria.
}

\begin{abstract}
In the face of economic depression and technological advancements round the world, there is growing need to design a computerized monitoring system in a bid to adapt to the global trend in financial management. The existence of computerized economic growth system in relation to the ministry of finance requires a higher dependent scheme of measure in financial control of the federation. Various departments exhibit responsibilities for revenue generation and financial plan structured to detail projections on income and expenses on long term and short term basis i.e. financial budget. The measure of financial terms is represented by stage processing of input in each sector that makes up the economy. This results to a yearly analysis of a dependent economic report within a country i.e. GDP Gross Domestic Product.
\end{abstract}

Keywords: Economic growth, financial management, financial budget and GDP.

\section{Introduction}

The federal ministry of finance was established in 1958 by the finance (control and management) ordinance, to replace the finance department. The ordinance conferred on the ministry is the responsibility for the control and management of the public finance of the federation. In the year 1980, attempts were made to reorganize the finance ministry either by exiting some of its departments or ceding others to it. For example, in 1980 Budget office became an extra Ministerial Department under the executive office of the president and headed by a special Adviser to the president on Budget matters, from 1987 the Budget office functioned once again under the ministry of finance and was surprised by its own merged with the ministry of National planning to form the office of Budget and planning in the presidency under ministry of state. Then in 1991, the Budget office was excised again from the ministry of budget and planning and returned to the ministry of finance where it is till date.

In the case of the customs, it was a department in the ministry of finance until 1985, when it was transferred to the Ministry of Internal Affair where it was managed under the customs, immigration and prisons services board. But in 1992; customs was returned to the jurisdiction of the ministry of finance.

\section{ECONOMIC GROWTH IN RELATION TO THE FEDERAL MINISTRY OF FINANCE.}

As aforementioned, departments responsible for the measure of finance within the federation play an important role in the growth of the economy.

Economic growth explains the generalization of performance of domestic interelational activities all leading to the measure of standard in the economy. The federal ministry of finance in the position of a regulation institution adopts rules on the basis of maintaining and increasing economic standards through the channels responsible for financial control and management in the federation. federation.

As a result of self observation, the financial budget and revenue department are part channels of the

Financial budget in the sense of economic growth is a plan structured to detail projections on income and expenses on a long term and short term basis.

Budget of this type incorporates other aspects of budget strategies including the preparation of a detailed budgeted balance sheet, a section that functions as a cash flow budget and addresses the receipt of income and flow of expenses on an annual, semiannual, monthly and yearly basis.

The revenue department is made up of three divisions namely; revenue division, petroleum division and research and statistic division. Given this background, the functions of the department include monitoring, analyzing and reporting of the revenue inflow as from oil and non-oil revenue source(s).

In addition, the federal ministry of finance carries out revision exercise on monthly and quarterly basis, in respect of revenue from the sources (customs and excise duties including levies, company income tax, federal government independent revenue earned by Ministry sector and operating surplus from major government parastatals. 


\section{Statement of the Problem}

Every organization is comprised of individuals that are recruited to offer diverse kinds of services, the cost of acquiring this task is translated into the payment made for carrying out this services.

Economic Growth Monitoring is an important aspect of any developing country particularly Nigeria. The Federal Ministry of Finance which is in the position to monitor and forecast Economic Growth has for some time now been running their office activities manually. Thus the Federal Ministry of Finance is associated with the following bottlenecks.

1. As identified in the case study, improper attempt has been made to describe the Nigerian Economic Growth in relation to the nation's development.

2. Incompetent members of staff carrying out the Economic Growth monitoring activities in the ministry: summarizing, analyzing and collection of data.

3. Poor record documentation.

4. Non-computer literate members of staff

5. Inaccuracy in Economic Growth Forecasting

The bottlenecks create depression of growth and development in standards of the economy.

The purpose of carrying out this research is as stated below:

\section{Significance of the Study}

(1) To demonstrate that computer can actually eradicate some abnormalities in Economic Growth Monitoring system in the Federal Ministry of Finance.

(2) To show the thorough put of computerized Economic Growth Monitoring.

(3) Amongst all to computerize the Economic Growth Monitoring process in Federal Ministry of Finance.

\section{Objectives of the Study}

Having identified some major problems in the Federal Ministry of Finance, the objective of this study is thus stated as follows:

1. Properly analyze the problem of the present system.

2. Design and develop a computer-based solution for Economic Growth Monitoring system that will help to forecast economic growth properly.

3. Develop a program that describes the economic growth in numerical terms; gross domestic, inflation rate (increasing or decreasing) wage, price and employment.

\section{Scope and Limitations of the Study}

This research work is restricted to the Economic Growth Monitoring department Federal Ministry of Finance. Although it ought to cover the whole of the ministry in the federation, due to time, finance and other logistics I had to limit myself to Abia state branch.

In economic growth monitoring, several processes are adopted, depending on the need. Partitioning of organization is one of such.

The following constraints were experience during the course of this work:

- Insufficient materials to carry out the research study.

- Poor attitude of staff in the ministry to give useful information form the basis for another challenge encountered during the course of this project.

- Time and finance are major factors that militated against this research work.

\section{Background of the Case Study}

The Nigerian Ministry of Finance is the government body that manages the finances of the Federal Government of Nigeria, including managing, controlling and monitoring federal revenues and expenditures.

\section{- Services}

Services include collecting and disbursing government revenue, formulating policies on taxation, tariffs, fiscal management etc., preparing and managing the budget, preparing annual accounts for ministries, departments and agencies, managing federal debt and regulating the capital market.

\section{- Leadership}

A senior civil servant acts as Permanent Secretary of the minister, assisting the politically appointed Minister of Finance, who is a member of the President's cabinet.

\section{- Parastatals and Agencies}

The Ministry of Finance is responsible for a number of parastatals and agencies:

1. Office of the Accountant General of the Federation of Nigeria

2. Budget Office of the Federation

3. Federal Inland Revenue Service

4. Investment and Security Tribunal 
5. National Insurance Commission

6. NEXIM

7. Nigeria Deposit Insurance Corporation

8. Nigerian Customs Service

9. Security and Exchange Commission

\section{Organizational Structure of Ministry of Finance}

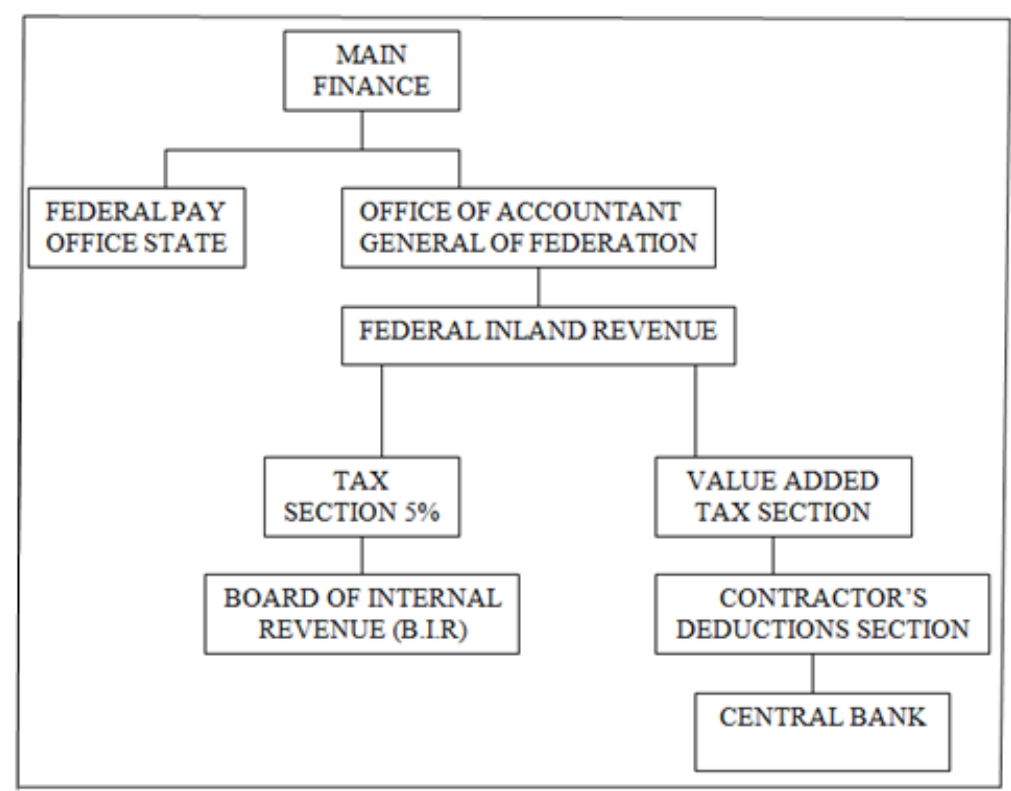

Fig 1: Structure of Ministry of Finance

\section{Research Methodology}

III. Research Methodology, System Investigation And Analysis

Research is a process of generating findings, which are used for rational decision-making and as a springboard for further research. It is the structured approach to a particular job such as system analysis and design.

Therefore, a research methodology is a structured approach of arriving at the dependable solutions to problems through the planning and interpretation of data. It is also a detailed description of what the research planned and procedures to be adopted in gathering of new facts relevant to this project work.

In the existing system where everything is manually operated, it is very tedious and complicated for instance, when one file in the system will be ransacked which is waste of time and energy. If the new system is applied it will only take a click of mouse to rectify the file that is needed rather, limited number of staff are employed which consume less money as wages and salaries where one or two computer will do the job of more than 75 people per day. The existing system makes use of typing machine which is manual. The economic growth monitoring system has no much access to enough fund to run the office efficiently and orderly without complaint from members of staff on allowances and salaries delay.

\section{RESEARCH METHOD USED}

The researcher used a number of methods in other to dig out the fact as to make this work study an efficient one. The following method was used.

a). examination of documents

b). personal observation

\section{EXAMINATION OF DOCUMENTS}

Documents which concerned the activities of the ministry was collected in order to closely adopt certain requirements to satisfy the system.

\section{PERSONAL OBSERVATION}

The researcher made out time to visit the ministry of finance in abia state (umuahia) information department and critically observed how operations were carried out in the department. 


\section{Method of Data Collection Used}

In the cause of trying to actualize the objective of this research work, I had to set up fact finding methods capable of providing data necessary to the solution of the problem since it is an indispensable process in any research work. Considering the fact that the problems and its many ramifications have been identified more clearly and thoroughly, I had to use both primary and secondary method of data sources. I had to synchronize the statement of the problem with the design to be used in its solution.

The primary data source used comprises of oral interview with some senior staff of the federal ministry of finance.

Secondary data generation used include amongst all, related work done by various authorities in the subject matter, News, magazines, journals, articles.

\section{System Investigation and Analysis}

This deals with critical examination of the facts obtained during the course of investigation of the system, It is from that the findings the study will be analyzed. In analyzing the facts, only those questions closely related to the research question will be analyzed.

\section{System Investigation}

This is the investigation of a system with the objective of knowledge and understanding how and the ways a system operates and to find out areas, procedures/subsystems that needs to be improved and possible procedures for such improvement. This deals with the ordering the breaking down of data collection into construction parts. It consists of statistical calculations performed with the raw data to provide answers to the question initiating the research. The analyst gathered facts in respect to the new system.

\section{Objectives of the Existing System}

The system has many forms that help it to operate well. The forms are as follows:

Form I: That is deduction form for tax and vat deductions that is the form used to write all the names of people in the nominal roll for tax deduction and (NHIS) National Health Insurance Scheme Deductions. P.E form popularly known as Personal Emolument form is used to payroll salaries of staff. It has the junior forms and senior personal emolument form.

Form 2: is for collection of revenue from other establishment like zoological revenue from Federal Ministry of Agriculture and revenue from Mining Department and Petroleum Product Return.

\section{Input, Process, Output Analysis \\ Input Analysis}

The major source of input to the system is called the Gross Domestic Product (GDP).

It's features are as shown below;

I. Gross Domestic Product per capital

II. GDP, agriculture

III. GDP, industry

IV. GDP, services

V. National budget

VI. Total revenue

VII. Total expenditure

VIII. Exports (oil, Agricultural product)

IX. Imports (Machinery and equipment)

\section{Process Analysis}

The processes involved in Nigerian economic monitory practice include;

Information about the above named economic factor is collected from the federal government and displayed based on proper statistical analysis.

\section{Output Analysis}

Using the above named factors of feature of the economy, the outputs are analyzed as follows;

Gross Domestic Product (GDP)

43,540 million as at (2002)

GDP per capital 30,300 (2002)

GDP Economic sector

GDP Agriculture 37.4 percent

GDP Industry $\quad 28.8$ percent 
GDP services

33.8 percent

National Budget

Total revenue

11,408 million (1995 estimate)

Total Expenditure

11,722 million (1995 estimate)

All this facts and figures are gotten from the Federal Revenue through the board of Internal Revenue and Federal Inland Revenue passed to the office of accountant general of the federation from which the pay office takes it up and finally stops at the office of the main finance for reviews and processing.

With this common framework, federal ministry of finance structures modifies the details of its specific monitoring reviews system. The facts and figures collection runs from a formal application to a length of forms of documents that is accomplished by detailed analysis of the required facts and figures.

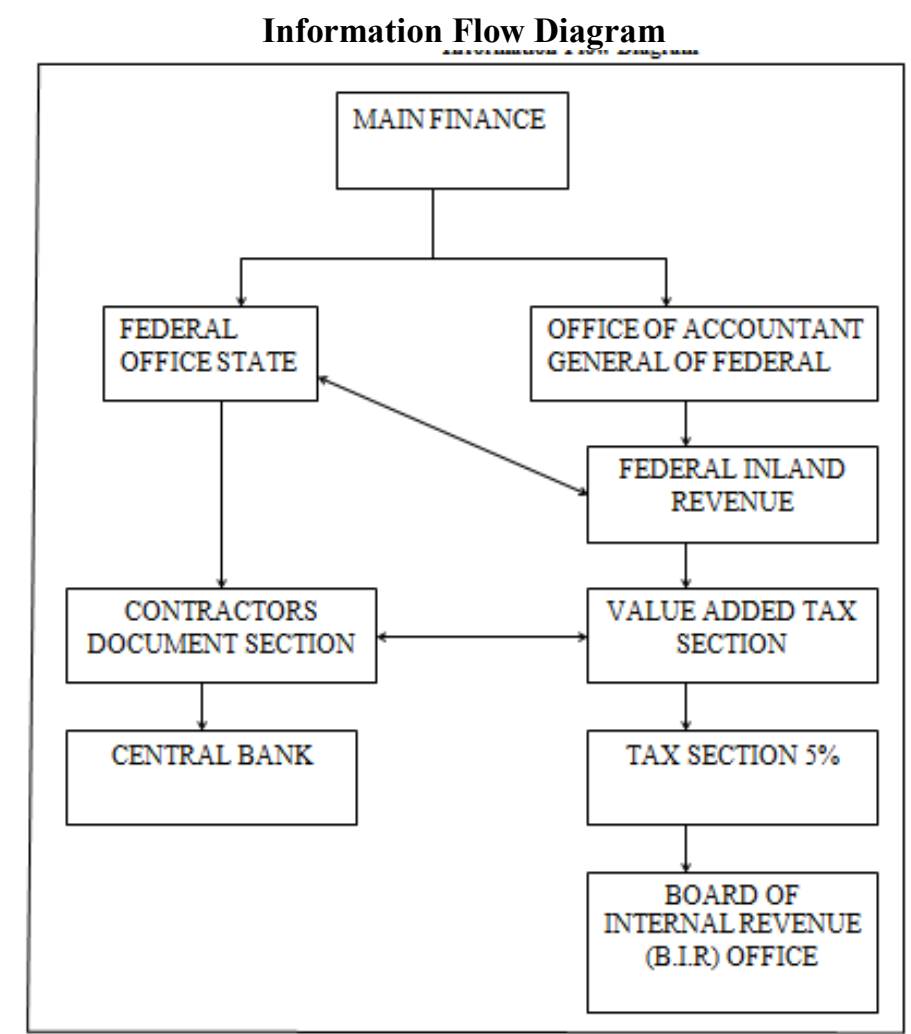

Fig 2: Information Flow Diagram

\section{Problems of the Existing System}

The already existing system which is manually operated and its very tedious and complicated. For instance, when a file for one project is needed, all the files in the system will be ransacked, and this is a waste of time and energy. But if the new system is applied it will only take some seconds to search for a particular file.

Another problem of the existing system is that the old system is made up of many staff which consumes more money via wages and salaries while one or two computers will do the job of more than 75 people per day.

Most of the sections of existing system were occupied by old and outdated machines and typing machines, as it is no more reliable in modern day application of division of labor.

The existing system of economic growth and monitoring does not have enough access to run the office efficiently and orderly without complaint from staff about allowances and salaries delay.

\section{Justification for the New System}

In an attempt to get an accurate computerized monitoring system, the new system was given birth to. If the existing system was highly computerized, there will be no need to create or implement the new system. Some of the importance of the new system is outlined below, viz:

* The system will provide an easier and quick access to online application to its subjugated packages which will ease the stress of economic growth monitoring in federal ministry of finance.

* The new system is a help to both the employer and employee because it will be easily accessed on a modern computer for quick and accurate data. 
* The new system will reduce the much voluminous books and papers of which the offices looked like where papers of different sorts are dumped. It will now be reduced to diskettes.

\section{Overview of System Design \\ IV. System Design And Implementation}

System design is an act of deriving or inventing a partially or compute new scheme. It is a creative function. It involves improving on the lapses or setback. Some of the following points are usually taken into consideration:

1) Re-appraisal in the light of result so far obtained.

2) To view again on the analysis of the existing system particularly any weak point and any unexpected discovery.

3) Decide if the system is perfect or can an analyst predict completely the requirement of any system in the future, therefore flexibility should be in accurate into all parts of the system.

\section{Input Design}

The inputs to the system are on screen, they include the menu: This aspect is concerned with building the records that will be displayed in the output form for Economic Report.

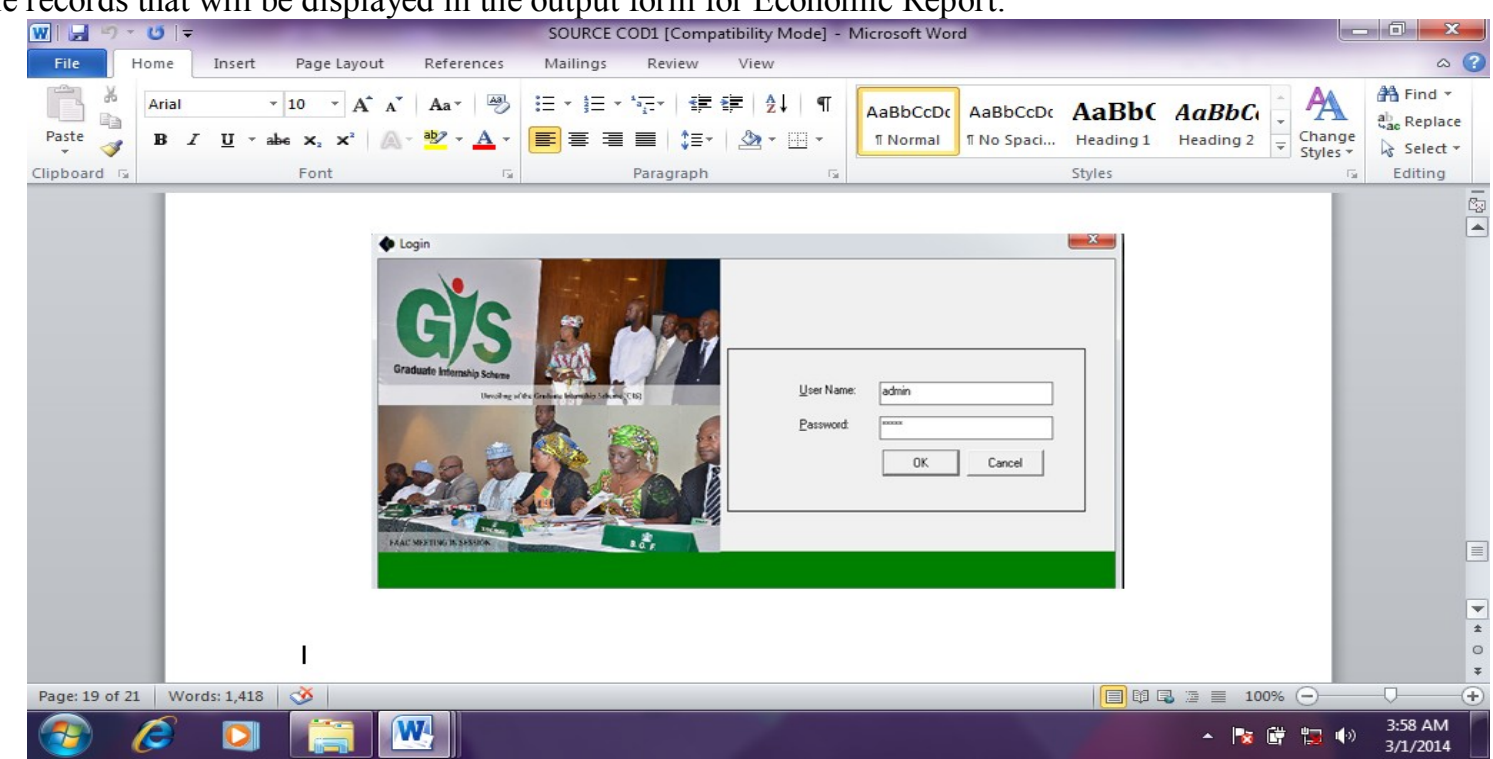

Fig. 3: The Login Input Page

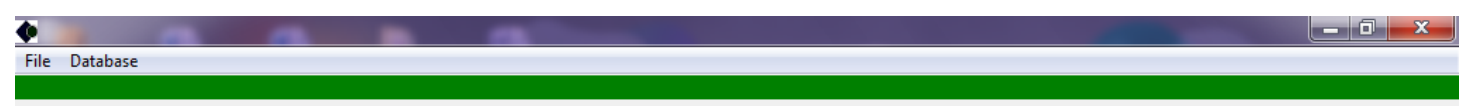

Federal Ministry of Finance Growth Economic Monitoring Team

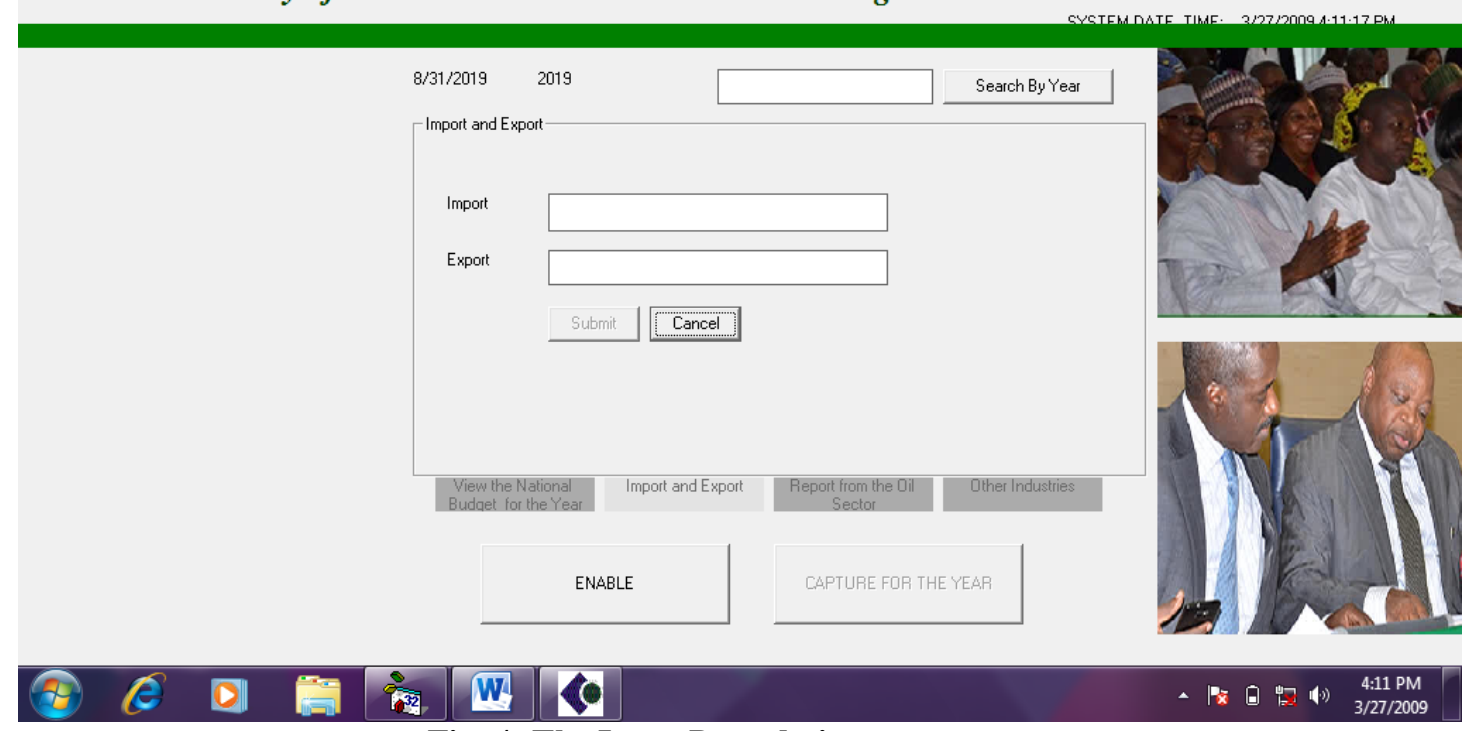

Fig. 4: The Input Page design 


\section{Process Design}
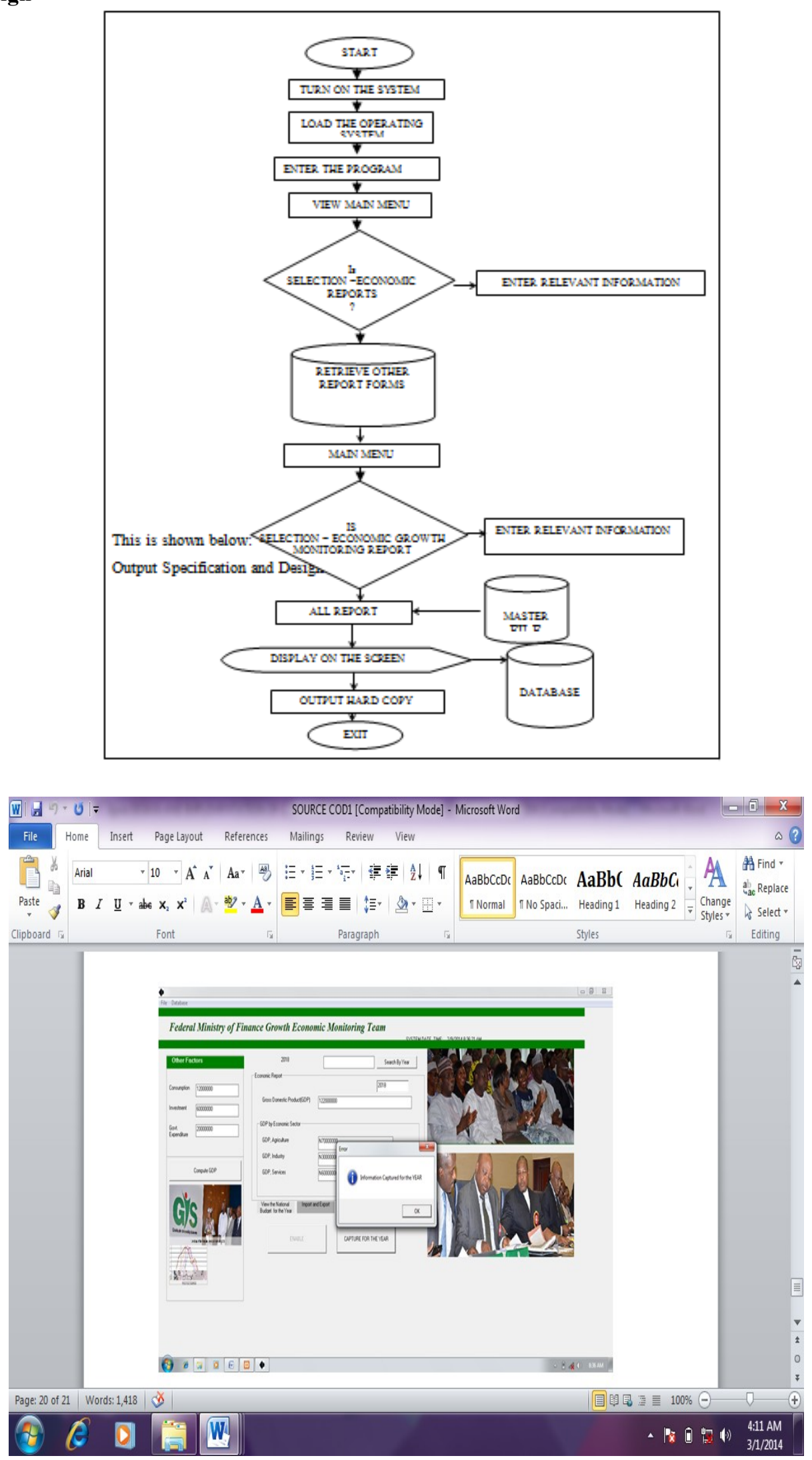

Fig. 5: Output Design Page 1 


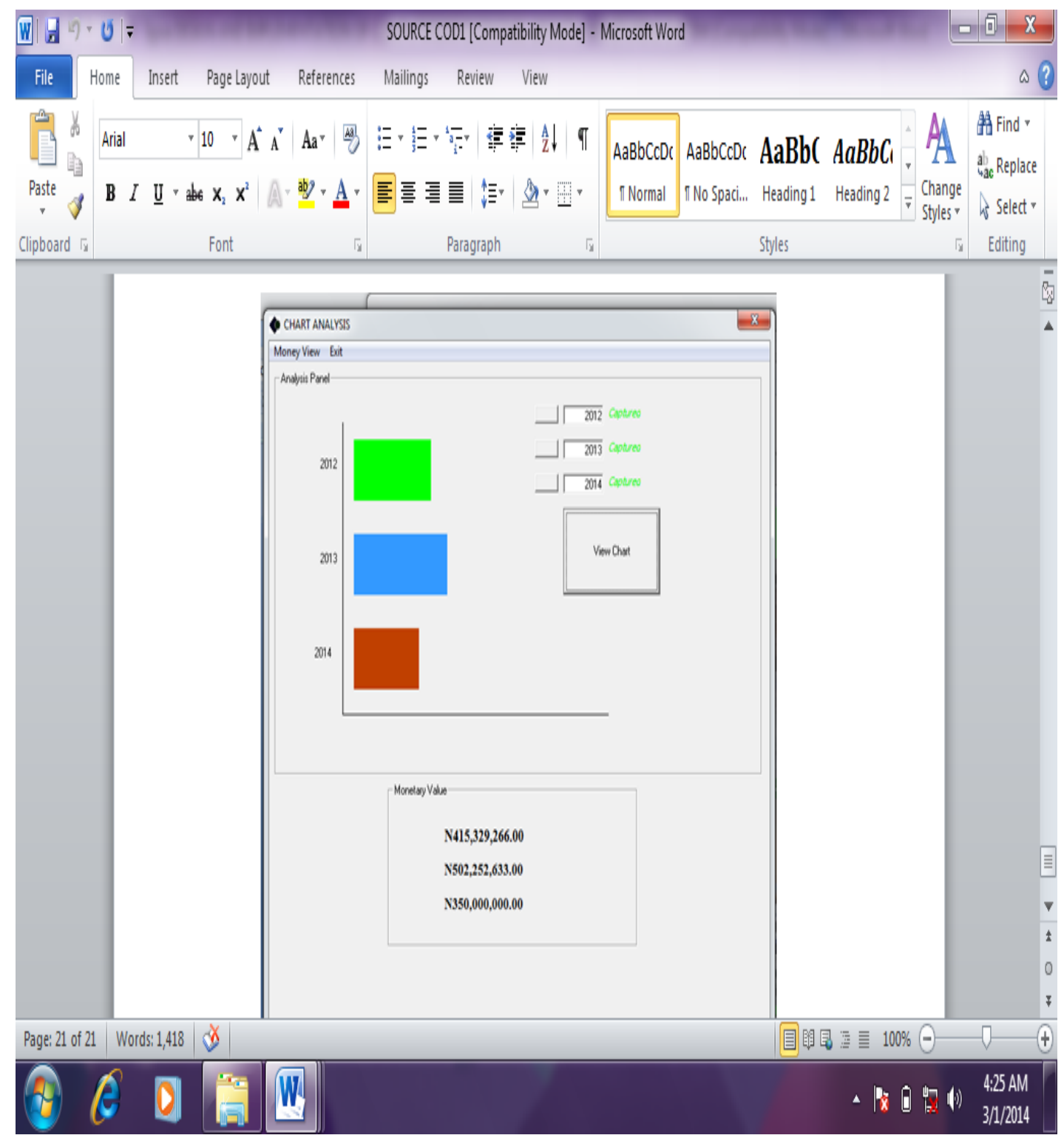

Fig.6: Output Design Page 2

Database Design

For the storage and processing of the information in the system, the master file named Economic Report would be used. The files used by the new system are made up of: Economic Growth Monitoring Report form, Oil Section Report form, National Budget Report form and other Industries.

\begin{tabular}{|l|l|l|}
\hline File Name & Field Length & Field Type \\
\hline GDP & 15 & Number \\
GDP per capital & 15 & Number \\
GDP, Agriculture & 15 & Number \\
GDP, Industry & 15 & Number \\
GDP, services & 15 & Number \\
Total Revenue & 15 & Number \\
Total Expenditure & 15 & Number \\
Imports & 15 & Number \\
Exports & 15 & Number \\
\hline
\end{tabular}

Fig7: Database Design Table 


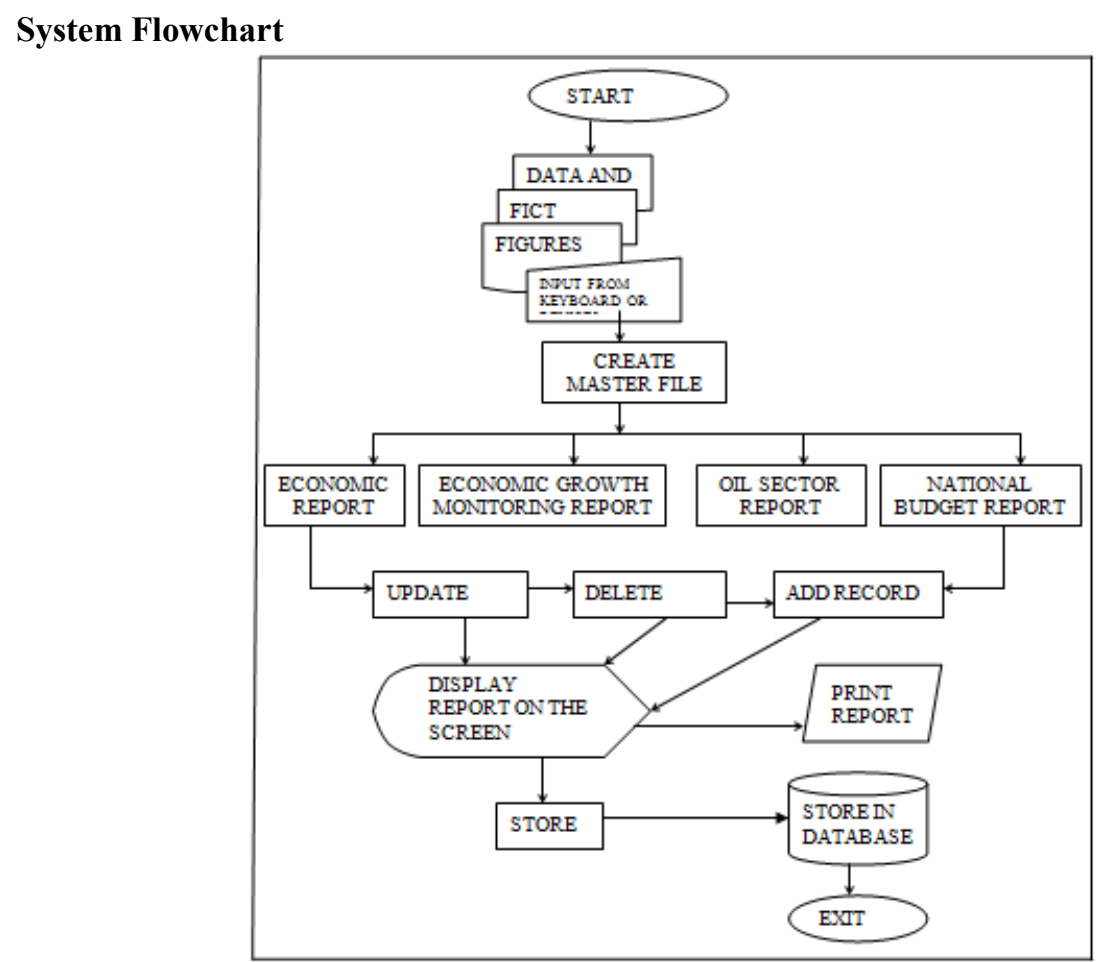

Fig.8: System Flowchart

\section{Program Design}

The program was designed in forms and codes which compares together to give the desired output requirements. The forms are concerned with the design of the structure and the output format of the new system. The code on the other hand gives the system a logical expression that will aid the logical flow of the program.

\section{Program Flowchart}




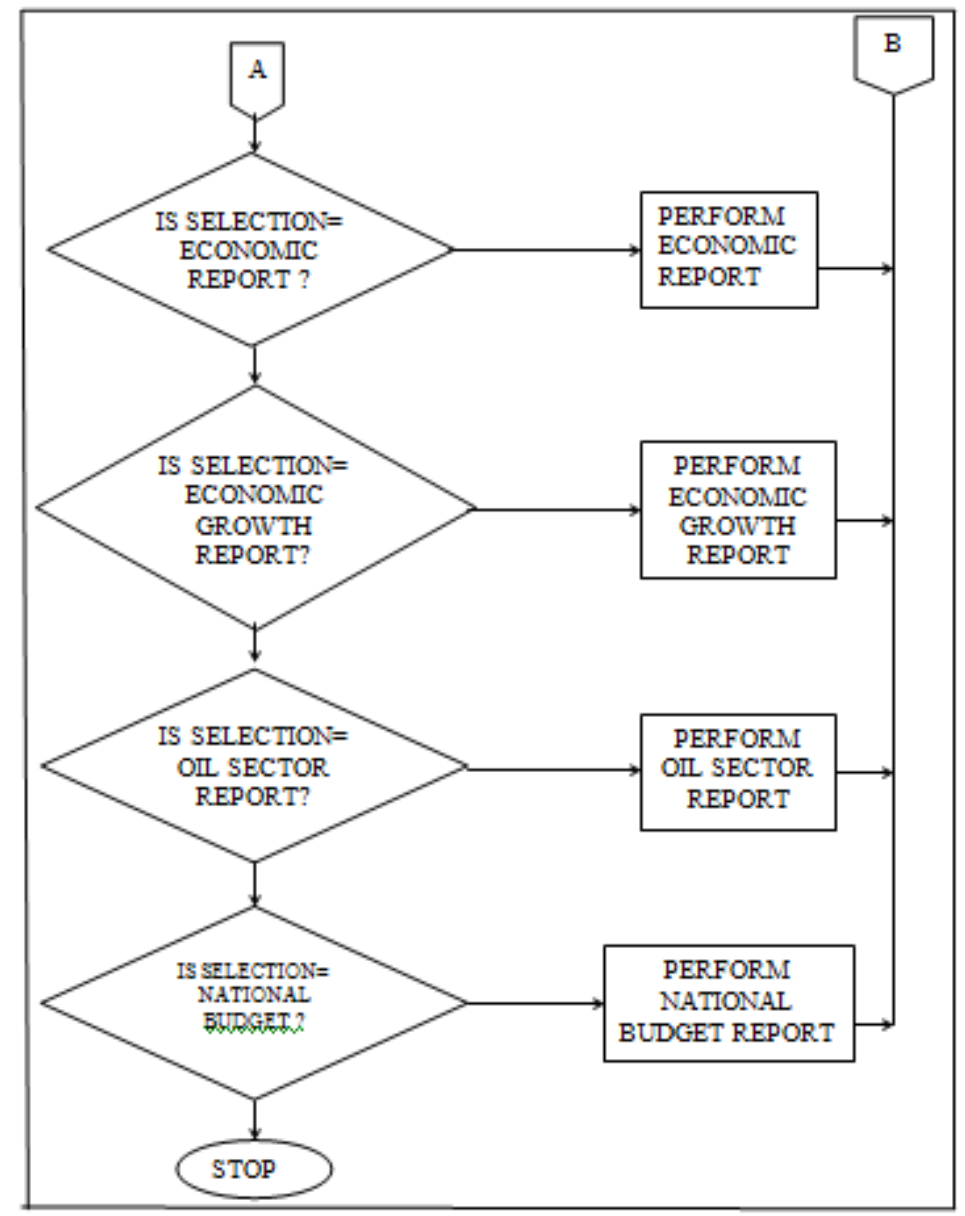

Fig.9: The Program Flowchart

\section{System Implementation}

In implementing the new system, certain factors are being considered before the final implementation process. These include: testing of the new system, the conversion method and the personnel involvement in the design, and implementation stage.

$>$ Testing: The new system had to undergo certain testing using some established facts and data to actualize the expected result of the system. If the result is achieved when compared with the existing result, then the new system has actually achieved the expected goal and objective of the design.

> Conversion: After testing of the new system, the next to consider is the method of implementation of the system into the organization or in order not to disrupt operations of the system. The system that was designed was implemented using parallel approach. This approach is being done using the new system and the existing system hand in hand. This approach will help the old system to adapt very well to the new system.

> Human Factor: The human factor in the implementation is another important factor in the design of the new system. This area concerns the personnel that will handle the new system. The new system is going to be handled by one expert with vast knowledge in computer programming. Also the staff of Federal Ministry of Finance will have to be trained on how to use the new system.

\section{System Requirement}

The new system design requires some basic components both in hardware and software which must be met for the full implementation of the new system. These requirements are categorized in the following headings

$\rightarrow$ Hardware Requirement

$\rightarrow$ Software Requirement

\section{Hardware Requirement}

This has to do with the basic hardware needed by the new system for optimal performance. Any system design will include the following: 
- A Pentium III and above (processor)

- A memory (say $256 \mathrm{MB}$ ) RAM SIZE and above

- A Visual Display Unit (monitor SVGA 14")

- A Hard disk (50-60G) or higher size

- Other hardware component includes the mouse, the keyboard and the LaserJet (black and white printer)

\section{Software Requirement}

The operating system could be any of the following: Windows 2000, Windows XP professional or Windows Server 2003, windows 7 and windows 8.

For the sake of building application in the future, it is suggested that Visual Basic 6.0 enterprise addition should be installed on the system. This will also help in a situation where the program needs modification.

\section{Project Costing}

It is the practice of creating financial reports specifically designed to track the financial progress of a project, which can then be used by managers to aid project management. It entails the total project costs which includes design fees, material cost, financing and other costs that were incurred incompletion of this project.

This project cost is considered based on;
i. $\quad$ Cost estimate of Hardware
ii. Cost estimate of Software
iii. Logistics Cost

- Cost Estimate of Hardware

\begin{tabular}{|l|l|l|}
\hline Quantity & Details & Amount \\
\hline 1 & Samsung laptop & $\# 100,000$ \\
\hline 1 & Laser jet Printer & $\# 25,000$ \\
\hline TOTAL & & $\# \mathbf{1 2 5 , 0 0 0}$ \\
\hline
\end{tabular}

Fig10: Cost Estimate of Hardware Table

- Cost Estimate of Software

\begin{tabular}{|l|l|l|}
\hline Quantity & \multicolumn{1}{|c|}{ Details } & Amount \\
\hline 1 & Microsoft Disk Operating System & $\# 20,000$ \\
\hline 1 & Microsoft 2007 Access & $\# 4,000$ \\
\hline 1 & Microsoft Visual Basic 6.0 & $\# 6,000$ \\
\hline 1 & System and Program Design & $\# 10,000$ \\
\hline 1 & Kaspersky Antivirus & $\# 15,000$ \\
\hline TOTAL & & $\mathbf{\# 5 5 , 0 0 0}$ \\
\hline
\end{tabular}

Fig 11: Cost Estimate of Software Table

\section{- Logistics Cost}

\begin{tabular}{|l|l|}
\hline Description & Amount \\
\hline Transportation & $\# 20,000$ \\
\hline Miscellaneous Expenses & $\# 25,000$ \\
\hline TOTAL & $\mathbf{\# 4 5 , 0 0 0}$ \\
\hline
\end{tabular}

Fig12: Logistics Cost Table

Considering the above mentioned cost estimates, the project cost is therefore the summation of logistics cost, software estimate cost and the hardware estimate cost.

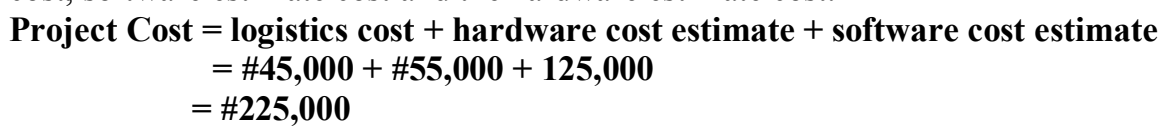

\section{System Maintenance and Evaluation}

The new system needs to be evaluated from time to time to dictate some setbacks of the computer, and if there is anything that will hinder effective running of the system and make it deviate from its target aims. During the system evaluation, any setbacks dictated should be corrected or maintained. The maintenance stage of the newly implemented system will include the efforts taken to ensure that the system continuously meets with the needs of the organization or company.

The designed system used should be monitored and maintained so that system breakdown will not occur and even if this eventually occurs, the situation will be identified and corrected immediately. Maintenance should cover software (programs) and hardware (peripheral devices) and human ware. 


\section{Conclusion}

Economic Growth Monitoring is an important aspect of any developing country particularly Nigeria. The Federal Ministry of Finance which is in the position to monitor and forecast Economic Growth has for some time now been running their office activities manually as this project demonstrates that computer can actually eradicate some abnormalities in Economic Growth Monitoring system in the Federal Ministry of Finance.

This led to the design of a computer-based solution for Economic Growth monitoring system that will help to forecast economic growth properly

\section{Recommendation}

However, as a result of Time constraint, I was unable to carry along every department available in the Ministry; so I am of the opinion that this work be assigned to other students so they can work on other part of this work.

In that view, I recommend that the safety of information within the Economic Growth Monitoring System be ensured in a systematic manner. Adequate means of "backup" disc files should be done at each run time. Preferably, the backup process should be done during the update routine and the resulting files dumped onto a secondary storage device. Hence, when any of the files in use are lost or accidentally destroyed, the update program can be used to retrieve the duplicate stored in the back-up.

The researcher also hereby recommends that the federal ministry of finance turn to Electronic Data processing (EDP) systems.

\section{Conclusion}

Due to the numerous difficulties involved in computerizing a manual system, it is imperative that the analyst commences with an explicit and unambiguous definition of the functions, objectives and limitations of the current system. This is so because it is easy to lose sight of the actual direction the study should follow when buried under a heap of tedious tasks. Though computers provide a lot of flexibility, I nonetheless recommend and pronounced them as a remedy to the ECONOMIC GROWTH MONITORING SECTIONS IN FEDERAL MINISTRY OF FINANCES's short comings.

However, as the study advanced, so did the conviction grow that any hypothesis was consistent with the result obtained. I am therefore confident in stating that Federal Ministry of Finance needs a more realistic computerization if it is going to be capable of performing at efficient levels.

\section{References}

[1]. Arestis, P., P. and Demetriades, (1997: 783- 799): "Financial Development and Economic Growth: Assessing the Evidence", the Economic Journal, Washington.

[2]. Arestis, P., P.Demetriades and K.Luintel (2001:16-41), "Financial Development and Economic Growth: The Role of Stock Markets," Journal of Money, Credit, and Banking. World Bank, Zurich.

[3]. Aziz, J. and C. Duenwald.(2002): "Growth-Financial Intermediation Nexus" IMF Working Paper, China.

[4]. Afangideh, U. J (June, 2009): "Financial Development and Agricultural Investment in Nigeria: Historical Simulation Approach", West African Journal of Economic and Monetary Integration Vol. 9. Nigeria.

[5]. Agu, C.C. and J.O. Chukwu (2008:189-190): "Toda and Yamamoto causality tests between bank based financial deepening and economic growth in Nigeria".European Journal of Social Science, Calabar.

[6]. Bencivenga, V.R. and B.D Smith (1991:403-404), "Financial Intermediation and Endogenous Growth", Review of Economic Studies, Sunderland.

[7]. Boyreau-Debray, G. (2003): "Financial Intermediation and Growth: Chinese style", Policy Research Working paper No. 3027, World Bank, Austria.

[8]. Christopoulus, D. and E. Tsionas (2004: 55-74): "Financial Development and Economic Growth: Evidence from Panel Unit Root and Integration tests", Journal of Development Economics, Toronto.

[9]. De Gregorio, J. and P.E .Guidotti.(1995: 43-48): "Financial development and economic growth",World Development, Georgia.

[10]. Demirguc-Kunt, A. and Levine, R. (1996: 223-239): "Stock Markets, Corporate Finance and Economic Growth: An Overview," World Bank Economic Review, Australia.

[11]. Demirguc-Kunt, A. and Levine, R. (2001):"Financial Structures and Economic Growth: A Cross-Country Comparison of Banks, Markets and Development", MIT Press Cambridge.

[12]. Greenwood, J. and B. Jovanovich (1990: 1076- 1107): "Financial development, growth and the distribution of income", Journal of Political Economy, Italy.

[13]. Hicks, John (1969):"A Theory of Economic History", Clarendon Press, Oxford.

[14]. Levine and Ross (2004): "Finance and growth: theory and evidence", NBER Working Paper Series, Õhklohama.

[15]. Levine, R. and Zervos, S. (1996:323-339): "Stock Market Development and Long- Run Growth", World Bank Economic Review 10, Washington D.C.

[16]. Ndebbio, J.E. (2004): "Financial deepening, economic growth and development: Evidence from selected sub-Saharan African Countries", Research Paper 142 African Economic Research Consortiums, Nairobi, Kenya.

[17]. Nnanna, O.J (2004): "Financial Sector Development and Economic Growth in Nigeria", Economic and Financial Review Sept. Vol. 42 , No. 3, Nigeria.

[18]. Nyong, M.O. (1994):"Dollarisation, national currency and seigniorage in Sub- Saharan Africa: The case of Nigeria 1986-1992", Working Paper, Department of Economics, University of Calabar, Nigeria.

[19]. Nyong, M. O. (1996): "Capital market development and long-run economic growth: Theory, evidence and analysis", Working Paper Series No.2, Department of Economics, University of Calabar, Nigeria. 
[20]. Nzotta, S.M and E. J. Okereke (2009): "Financial deepening and economic development of Nigeria: An Empirical Investigation", African Journal of Accounting, Economics, Finance and Banking Research Vol. 5, University of Nsukka, Nigeria.

[21]. Ogun, O.D. (1986: 275-283): "A note on financial deepening and economic growth: Evidence from Africa", The Nigerian Journal of Economic and Social Studies, 28(2), Lagos.

[22]. Sachs et al (1995: 1-18): "Economic Reforms and the Process of Global Integration," Brookings Papers on Economic Activity, No. 1 , Manchester.

[23]. Schumpeter, Joseph (1912):" The Theory of Economic Development", Mass Harvard University Press, Cambridge.

[24]. Shan et al (2006:231-234)," Does Financial Development Lead to Economic Growth? The case of China", Annals of Economics and Finance 1, China.

[25]. Shan et al (2001:443-445):"Financial Development and Economic Growth", Review of International Economics 9, Florida. 